\title{
The Views of Tokat Tax Office Employees Regarding the Rights and Obligations of Taxpayers
}

\author{
Deniz ŞAHIN \\ deniz.sahin@gop.edu.tr
}

Elvan CENIKLİ

elvancenikli@mu.edu.tr

\section{Tokat Vergi Dairesi Çalışanlarının Mükellef Hak ve Ödevlerine İlişkin Görüşleri}

\begin{abstract}
As the importance of taxpayers' rights and obligations rises, the analysis of the extent to what taxpayers and the employees of revenue authority (RA) are aware of taxpayer rights and obligations and to what extent they comply with them increases in importance. The present study aims to evaluate this issue based on the opinions of Tokat Tax Office (TTO) employees and employs qualitative research methodology. According to the research results, it is understood that there is a certain level of consciousness and knowledge regarding taxpayer rights and obligations in Turkey. However, it is clear such knowledge and consciousness are not at a sufficient level and there is need for more studies on this subject in order to reach the desired level.
\end{abstract}

Keywords

: Taxpayer Rights, Taxpayer Obligations, Taxpayers' Declarations, Revenue Authority, Tax Office.

JEL Classification Codes $\quad: \quad \mathrm{H} 200$.

\section{Özet}

Mükellef hak ve ödevlerinin bilinmesi ve korunmasının önemli hale gelmesine eşanlı olarak mükellef hak ve ödevlerinden vergi mükelleflerinin ve gelir idaresi çalışanlarının ne kadar haberdar olduğu ve ne ölçüde gözettiğini değerlendirmek de önem kazanmıştır. Bu konuyu gelir idaresi çalışanlarının görüşlerine dayalı olarak değerlendirmeyi amaçlayan bu araştırmada nitel araştırma yöntembilimi benimsenmiştir. Araştırma sonuçlarına göre; Türkiye'de mükellef hak ve ödevlerine ilişkin belli bir bilgi ve bilinç düzeyinin olduğu anlaşılmaktadır. Ancak henüz yeterli bir düzeyde olmadığı ve istenen etkinliğe ulaşılması için daha bazı çalışmaların yapılmasına ihtiyaç olduğu ortaya çıkmıştır.

Anahtar Sözcükler
: $\quad$ Mükellef Hakları, Mükellef Ödevleri, Mükellef Bildirgeleri, Gelir İdaresi, Vergi Dairesi. 
Deniz ŞAHIN \& Elvan CENIKLI 


\section{Introduction}

Attempts to ensure the legal security of individuals since the 1990s and the restructuring efforts based on the New Public Administration (NPA) mentality have resulted in the acceptance of a "taxpayer-focused" structure in revenue administration. In this context, "taxpayer rights and obligations" have received attention, and the development of mechanisms in order to raise awareness for and comply with such rights and obligations has been featured. In this direction, many countries have announced taxpayer rights and obligations based on their conditions and developed mechanisms in order to protect them.

Taxpayer rights and obligations, which are the most important requirement to increase the efficiency of revenue administrations, have attracted the attention in Turkey in parallel with the developments around the world. In line with such increased attention on this quite debated issue, the evaluation of the extent to what taxpayers and revenue administration employees are aware of taxpayer rights and obligations and to what extent they comply with has gained importance. However, the related literature in Turkey contains just one empirical study (Çetin \& Gökbunar, 2010) in this matter.

Therefore, the aim of this study is to reveal some findings and evaluations regarding the extent to what taxpayers and revenue administration employees are aware of taxpayer rights and obligations and to what extent they comply with them based on the opinions of revenue administration employees. For this reason, first taxpayer rights and obligations are examined conceptually. In order to concretize the subject, some findings and evaluations are brought forward in regard to taxpayer rights and obligations by means of an open-ended survey through the investigation of the opinions of the employees at Tokat Tax Office who directly interact with taxpayers.

\section{Conceptual Framework}

The tax obligation, which is a constitutional obligation, brings a liability to the ones who bear this obligation, and some rights and obligations come out when a person becomes a taxpayer (Arslan, 2008: 2). These rights and obligations are important in terms of the development of the relationships between taxpayers and revenue administrations (Egeli \& Dağ, 2012: 130). These rights and obligations serve for the development of a trustworthy environment and collaboration between taxpayers and revenue administrations. They also allow experiencing a more efficient taxing process.

From a legal point of view, "obligation" means the acts and behaviours that need to be obeyed and fulfilled as per the laws. In this context, according to the tax laws, the most important duty of taxpayers is to pay their tax debts within the period, amount, and form set by the laws. This is a financial obligation. On the other hand, there are also formal 
obligations that arise from being a taxpayer and enable the sound fulfilment of the financial obligations until the tax debt is paid. These formal obligations enable taxpayers to participate in the process of taxing, help decrease the workload of the administration, and provide efficiency in fulfilling the tax obligations. This is because taxpayers are a party of the tax, and they cannot be excluded from the process (Arslan, 2008; Egeli \& Dağ, 2012: 131). On the other hand, the main rights of individuals in the general legal order appear in the tax law as "the rights of taxpayers" (Çetin \& Gökbunar, 2010: 24). The rights of taxpayers are "the rights which give an authority to taxpayers to make a positive or a negative request and which provide a legal protection in case of a violation" (Dönmez, 2004: 57). According to another description of taxpayer rights, they are the rights given to taxpayers in the legal relationship between the government and taxpayers during the taxing process (Gökbel, 2000). The rights of taxpayers before the government (taxpayer rights) are as important as their obligations (Erol, 2011: 2). They allow handling tax administration from taxpayers' point of view and enable taxpayers to comply with taxing (Çetin \& Gökbunar, 2010: 23). The tax compliance means the assurance of rights for taxpayers and the assurance of tax income for revenue administration. This is because; while the protected rights result in the increased consciousness of taxpayers and timely and perfect fulfilment of tax obligations, the violated rights lead to taxpayers' avoidance of tax payment and therefore the decrease of the public revenue.

Up until now, the focus has been mostly on the "tasks and obligations of taxpayers", and "the rights of taxpayers" have been disregarded (Gerçek, 2006). However, attempts to protect individuals before the law have featured taxpayer rights as a result of the increased importance of human rights (Çetin \& Gökbunar, 2010: 24). This is because; the concept of taxpayer rights is closely associated with the concept of human rights. The Magna Carta Libertatum dated 1215 can be regarded as the beginning of taxpayer rights and law. They essentially became a matter of discussion in the fourth quarter of the $20^{\text {th }}$ century as a result of increased human rights movements after the World War II (Gerçek, 2006; Brzezinski, 2010: 17). In this context, taxpayer rights went through a series of waves. They are as follows (Bentley, 2002: 1):

- The first wave includes the definition and formation of the modern tax system. In this process, fundamental rights such as "right to review tax decision" and "rights in tax collection and application processes" have been featured.

- The second wave involves the development of legal and administrative framework to manage the intense interaction between tax authorities and taxpayers. This process has featured "provisions such as privacy, confidentiality (immunity), and search/seizure and issues regulating certain tangible rights and procedural rights such as providing a series of administrative rights to facilitate the administrative process". 
- The third wave includes the establishment of a tax framework for enhancing foreign direct investments and trade as well as the official acceptance of declaration of taxpayer rights in order to increase voluntary compliance.

- $\quad$ The fourth wave includes increased supranational protection based on trade blocks and agreements.

Taxpayer rights, which have emerged with the belief that individuals have also rights on the issues which they have obligations for, are accepted in many countries. Recently, they have even started to be accepted internationally in line with the developments in basic individual rights (Er, 2011: 3). Moreover, efforts made to enable the voluntary tax compliance, to establish collaboration with the revenue administration, and to give priority to taxpayer in taxing have also highlighted taxpayer rights (Buyrukoğlu \& Erasa, 2012: 117125). In this sense, it is now clear that there is a need to establish the relationship between taxpayers and revenue administration in such a way that gives taxpayers some rights and possibilities for an effective and fair taxing (Kızılot \& Taş, 2011: 16). Moreover, attention given to efforts to identify, explain, protect, and audit taxpayer rights is regarded as an indicator of a country's approach to the taxing process and taxpayers. Hence, the countries which are reconstructing their revenue administrations adopt a functional and taxpayerfocused structure and attach importance to structuring and explaining taxpayer rights in this process (Gerçek, 2006). In this context, many countries attempt to clearly define taxpayers' rights and obligations which arise from their tax-related procedures by announcing the "declarations of taxpayer rights" or "privileges in taxpayer rights" which aim to express taxpayers' rights and obligations plainly (OECD, 2002: 6).

In fact, taxpayer rights (though not sufficient) and obligations exist in the tax systems of all countries. Primary sources aimed at establishment and regulation of these rights and obligations exist almost in all countries (e.g. international agreements, constitutions, and provisions of law). However, regulations such as taxpayers' declarations and privileges are mostly secondary sources aimed at explanation and announcement of taxpayer rights, and they exist in few countries. Therefore, in the modern sense, developments regarding taxpayer rights and obligations have come to the fore as a result of declaration of taxpayer rights, the announcement of privileges in taxpayer rights, and the establishment of the units or departments which protect these rights.

The examination of the ways countries explain and announce taxpayer rights shows that countries adopt different methods depending on their democratic traditions, cultures, and administrative mentalities (Kızılot \& Taş, 2011: 16). According to a study conducted in 2003 by OECD, countries' tax policies, legal and administrative regulations, and cultures should be taken into consideration while preparing fundamental taxpayer rights and obligations which are included in the declarations of taxpayer rights. Thus, there is not one specific declaration model appropriate to all countries (Çetin \& Gökbunar, 2010: 27). 
The declarations of taxpayer rights issued in some countries are mostly regulated as a law and give the greatest attention to providing more taxpayer rights. In this way, as they are regulated as a law, the legal protection of taxpayer rights is ensured. The Privileges in Taxpayer Rights issued in some countries are administrative regulations which function as a guide to tax laws and include only the explanation of taxpayer rights of revenue administrations. These administrative regulations, which obviously provide comfort and an effective promotion for taxpayers in their relations with revenue administrations, increase the specificity in the taxing process and also augment the voluntary compliance of taxpayers with the tax laws (Bentley, 1998: 23).

Basic taxpayer rights can be listed as the following (The Republic of Turkey Ministry of Finance, 2002; Egeli \& Dă̆, 2012; Gerçek, 2006; OECD, 2002; OECD, 2003);

- The right to receive fair, equal, and respectful service,

- The right to be informed, assisted, and heard,

- The right of appeal (application),

- The right to certainty (the tax to be paid is to be certain in advance),

- The right to privacy,

- The right to tax confidentiality and privacy,

- The right to pay no more than the correct amount of tax.

Besides, "Taxpayers' Rights and Obligations - A survey of the legal situation in OECD countries", which was accepted and issued by the OECD Council on the $27^{\text {th }}$ of April 1990, identifies taxpayer obligations as the following (The Republic of Turkey Ministry of Finance, 2002; OECD, 2002);

- The obligation to be honest,

- The obligation to be co-operative,

- The obligation to provide accurate information and documents on time,

- The obligation to keep records,

- The obligation to pay taxes on time.

As mentioned before, another effort which is parallel to the announcement of taxpayer rights and obligations has been to develop mechanisms aimed at protecting them. Various institutions, organizations, and mechanisms have been established based on countries' legislative and executive traditions, cultures, and administrative mentalities. For instance, ombudsman is appointed for protecting taxpayer rights and dissolving 
disagreements in most countries. The Taxpayer Advocate has been established in the USA. Moreover, besides taxpayers associations in many countries, the World Taxpayers Association has been established in order to protect taxpayer rights. The main purpose of such associations is to ensure effectiveness, transparency, and accountability in the public sector, to protect the legal rights of taxpayers, and to simplify and clarify the tax laws. Furthermore, these associations, especially in the countries where taxpayer rights have just developed, have important roles in improving the collaboration between taxpayers and tax offices, simplifying and implementing the tax laws in a uniform manner, and training and informing taxpayers (Gerçek, 2006).

In Turkey, there are many regulations regarding taxpayer rights and obligations (e.g. in the Constitution, in tax laws, in secondary laws and regulations). Within the scope of these regulations, taxpayer obligations (arranged in the articles 153-257 of the TPL ${ }^{1}$ ) in Turkey can be listed as the following (Kızılot \& Taş, 2011: 93-108):

- The obligation to report (to report starting a job, to report quitting of a job, and inform the changes),

- The obligation to submit a declaration,

- The obligation to keep a book,

- The obligation regarding the recording order (the use of Turkish letters, the use of international numbers, the use of Turkish lira as the currency, approval of the books, and other issues),

- The obligation regarding documentation order (receipt, note of expenses, transport waybill, payroll, etc.),

- The obligation to keep and submit,

- Other obligations.

Taxpayer rights in Turkey can be listed as general rights and special rights as the following (Kızılot \& Taş, 2011: 109-110; Gerçek, 2006):

\section{General Rights:}

- The right to receive fair, equal, and respectful service (this is emphasized in studies for the introduction of a total quality management approach in tax offices),

I Tax Procedure Law. 
- The right to receive information (the articles 21 and 413 of the TPL),

- The right to apply (the articles 36,74,125 of the Constitutional Law; the articles $13,17,116-126,376,377$ of the TPL; the articles $15,20,58$ of the $\mathrm{LPCPR}^{2}$ ),

- The right of certainty in taxing (the article 73/1,73/2,73/3 of the Constitutional Law),

- The right of confidentiality of the information (the article 5 of the TPL; the article 107 of the LPCPR; the article 43 of LCPASCPA ${ }^{3}$ no 3568),

- The right to use a representative (articles 10, 332, 333 of the TPL; the repeated article 35 of LPCPR),

- The right of privacy (the articles 20,21 and 22 of the Constitutional Law; the articles $142,143-147,151$ of TPL).

\section{Special Rights:}

- Rights during assessment and collection (e.g. the right to sue, the right of petition, the right to apply to reduction institutions) / (articles 112, 115, 371 and 378 of the TPL; articles 23 and 48 of the LPCPR),

- $\quad$ Rights during the dissolution of the tax disagreements (e.g. the right to apply to reduction institutions, the right to get information, the right to appoint a person as an agent, the right to evidence based on circumstantial evidence) / (article 376 of the TPL; articles 17, 20 and 27 of the AJPL4),

- Rights during tax auditing (taxpayers can ask the auditor to show his photographed certificate, can avoid showing the books and documents if the certificate is not shown, and can request the tax examination to be conducted at the office and within the working hours) / (articles 129, 136,139 and 140 of the AJPL).

When Turkey is compared with modern countries in terms of the rights given to taxpayers, it is seen that a considerable amount of taxpayer rights exist in the Turkish tax law. However, they are not collective and systematic. They are more like provisions

\footnotetext{
2 The Law on Procedures of the Collection of Public Receivables.

3 Law of Certified Public Accountancy and Sworn in Certified Public Accountancy.

4 Administrative Jurisdiction Procedures Law.
} 
regarding organizations regulated by the laws. Therefore, the deficiencies of the Turkish tax law, its adequacy, and whether or not it provides the required protection should be discussed.

The contemporary tendencies for the reconstruction of tax administration since the 1990s has also accelerated the efforts aimed at reconstruction of revenue administration in Turkey. Many efforts were made in Turkey, especially in the early 2000s, in order to reconstruct revenue administration. At the end of this process, the reconstruction of revenue administration was achieved in 2005 in accordance with the law no. 5345. With this law, the target was to transform from the structure based on tax types, which was the basic trend in the reconstruction of revenue administrations across the world, into the functional and taxpayer-focused structure. As a reflection of the importance attached to this issue, the Taxpayer Services Unit was established, and "The Declaration of Taxpayer Rights" was published. "The Declaration of Taxpayer Rights", which was announced by the minister of finance Kemal UNAKITAN on the $25^{\text {th }}$ of February in 2006 in Erzurum, contained only the expressions that were parallel to the necessities that OECD stated in regard to the rights. Following this declaration, the Ministry of Revenue Administration prepared a brochure entitled "The Rights of taxpayers and the Obligations of the Administration in Tax Inspection" in 2007. However, the responsibilities and obligations of taxpayers were not mentioned. On the other hand, protective mechanisms such as taxpayer advocate and ombudsman have not been established in Turkey yet in order to ensure the adoption and implementation of taxpayer rights and obligations by tax administration and taxpayers.

In short, it is clear in Turkey that efforts and works regarding taxpayer rights and obligations are relatively new and some other conditions need to be achieved in order to obtain the intended effectiveness. Besides, attempts such as the taxpayer-oriented reconstruction of revenue administration taxpayers in Turkey and the announcement of "The Declaration of Taxpayer Rights" are important steps in terms of taxpayer psychology and tax consciousness. However, it should be noted that the success of these new attempts depends on truthfulness that taxpayers and the administration will show in practice. In other words, revenue administration should comply with rights truthfully, and taxpayers should fulfil its obligations truthfully (Öz \& Karakurt, 2007:87-88). Compliance with "taxpayer rights and obligations" primarily requires taxpayers and revenue administrations to have enough knowledge and consciousness taxpayers of this issue.

\section{Methodology}

\subsection{Model}

Qualitative research methodology was adopted in this study, which intends to evaluate the extent to what taxpayers and revenue administration employees are aware of 
their "rights and obligations" and to what extent they comply with them. In this context, typical case sampling was employed in the study. The reason for the use of typical case sampling was to acquire information about the thoughts of revenue administration employees regarding taxpayer rights and obligations and to inform the ones who were not aware of them. Therefore, Tokat Tax Office (TTO) was chosen for the sampling.

\subsection{Participants}

The respondents of the research consisted of the employees of TTO. There were 88 employees working there. Questionnaire forms were sent to all of the employees included in the sample. 63 of the questionnaire forms were sent back, and 63 of them were included in evaluation. $25.7 \%$ of the employees participating in the study were female, and $74.3 \%$ of them were male. $16.6 \%$ of the participants were high school graduates; $2.8 \%$ of them were elementary school graduates; and $80.6 \%$ had master's degrees. Of the participants, $51.1 \%$ has worked at the office for 10 years or more, $20.5 \%$ for 7 to 10 years, $6.8 \%$ for 4 to 6 years, and $21.6 \%$ for 1 to 3 years.

\subsection{Data Collection}

An open-ended questionnaire was used in order to collect data for the research. While the questionnaire questions were being prepared, various question categories (i.e. phenomenological, knowledge, attitudes-views, elimination, and drilling $)^{5}$ were created based on theoretical content and research purpose. In this context, a questionnaire form consisting of two parts and seven questions was developed. The first part of the questionnaire aimed to reveal the value and validity of the data obtained from the participants through phenomenological/elimination questions questioning the educational levels and working periods of the participants. There were two questions for determining the educational levels and the working periods (at the tax office) of the participants. The second part of the questionnaire form contained 5 open-ended questions intending to identify the knowledge levels and views of the participants on the research subject. The questions in four question categories such as knowledge, elimination, attitudes-views, and drilling were combined in

5 Phenomenological questions: They aim to get personal information about the respondents. Information to be obtained may be related to gender, age, profession, educational level, working period, etc. Knowledge questions: They aim to determine the knowledge levels of the respondents regarding the subject. They aim to determine what people know about the subject, how much they know, and the nature of such knowledge. Attitude-view questions: They aim to reveal the expectations, attitudes, beliefs, feelings, and views of the respondents about the subject. Elimination questions: They aim to determine those who are not knowledgeable of the research subject or those who do not have enough knowledge on it. Drilling questions: They aim to identify the reasons and justification of respondents'attitudes and views. 
such a way they would complement one another and were listed in a logical order. 5 questionnaire questions determined and listed are as follows:

1. What do you think are the obligations of taxpayers in their relationships with the tax office? (knowledge and elimination question),

2. Do you think that taxpayers who are in contact with the tax office that you work for fulfil their obligations? Why? (attitude-view and drilling question),

3. What do you think are the rights of taxpayers in their relations with the tax office?(knowledge and elimination question),

4. Do you think that the rights of taxpayers are complied with sufficiently at the tax office that you work for? Why? (attitude-view and drilling question),

5. Do you think it is important to know and comply with taxpayer rights and obligations? Why? (attitude-view and drilling question).

After obtaining expert opinion, the survey was conducted between the $2^{\text {nd }}$ and the $16^{\text {th }}$ of June 2013. The questions were responded by the tax office employees in written. In order to ensure the reliability of the research, the items of the questionnaire on which there was an "Agreement" and the items on which there was a "Disagreement" between the researcher and a person specialized in the field were identified through examination of the responses that the tax office employees gave to the open-ended questions. The formula provided by Miles \& Huberman (1994) was used for ensuring the reliability of the research, and the research was found to be reliable $(\mathrm{P}=96)$.

\subsection{Data Analysis}

The descriptive analysis technique, which is a qualitative research technique, was employed in the analysis of the data collected through the open-ended questionnaire in order to identify the opinions of the tax office employees regarding taxpayer rights and obligations. The data acquired through the descriptive analysis were interpreted through summarization based on the present themes. The obtained data were provided in tables along with relevant frequencies, and the opinions of the employees were provided in direct quotations.

\section{Findings and Interpretation}

In this section, the research findings are presented in tables, and direct quotations from Tokat Tax Office (TTO) employees' opinions are provided. 


\subsection{The Opinions of the TTO Employees Regarding Taxpayers' Obligations}

The frequency distribution of the answers given by the TTO employees to the question, "What do you think are the obligations of taxpayers in their relationships with the tax office?" is illustrated in Table 1.

Table: 1

The Opinions of the TTO Employees Regarding taxpayers Obligations

\begin{tabular}{|l|l|}
\hline "What do you think are the obligations of taxpayers in their relationships with the tax office?" & f \\
\hline & \\
Total Response & $\mathbf{6 3}$ \\
& 39 \\
Payment of the tax debt on time and in full amount according to the laws & 29 \\
Declaring on time, completely, and accurately & 27 \\
Submitting a declaration on time and accurately & 21 \\
Complying with the document format & 17 \\
Bookkeeping & 12 \\
Keeping and submitting the books and documents & 10 \\
Improvement of the tax consciousness (ethics) & 7 \\
Building good relations with tax office employees & 6 \\
Having knowledge & 3 \\
Being in contact with the tax office more closely and frequently & 1 \\
Having experienced accountants & 1 \\
Being up-to-date & 1 \\
Knowing how to seek one's rights & 1 \\
Following how the taxes are used & 1 \\
Considering their accountants as their financial advisors & \\
\hline
\end{tabular}

Table 1 indicates that the majority (39) of the TTO employees think that the main obligation of taxpayers is to make payment of the tax debt on time and in full amount according to the laws. Furthermore, they also expressed their opinions about the formal obligations required for the fulfilment of these financial obligations of taxpayers. Among the TTO employees who expressed their opinions regarding formal the obligations of taxpayers, 27 respondents said, "submitting a declaration on time and accurately"; 21 respondents said, "complying with the document format"; 17 respondents said, "bookkeeping"; and 12 respondents said, "keeping and submitting the books and documents". The TTO employees mentioned some further obligations which are not established clearly in the law except for the financial and formal obligations, but taxpayers have to comply with in the taxing process. In this context, $10 \%$ of the TTO employees told, "improvement of the tax consciousness"; 7\% told "building good relations with tax office employees"; 6\% told, "having knowledge"; and 3\% said, "being in contact with the tax office more closely and frequently". 
The TTO employees expressed their opinions about the findings of "payment of the tax debt on time and in full amount according to the laws", "declaring completely and accurately", "submitting a declaration on time and accurately", "complying with the document format", "bookkeeping", and "keeping and submitting the books and documents" by saying, "taxpayers should be aware of their responsibilities and obligations with citizenship consciousness"; "they should be as conscious while stating their earnings and making payment as they are while earning money and working to earn more"; "taxpayers should be conscious of their obligations in fulfilling tax-related transactions"; "taxpayers should be aware of their obligations, should be conscious while paying the tax debt, complying with the document format, giving the information that the tax office requires, submitting a declaration, and reporting the address changes, and shouldn't cause any difficulties for tax office employees. They should make the search before going to the tax office not to lose time of both sides"; "taxpayers should fulfil all their tax-related transactions on time, accurately, and completely"; "they should fulfil their responsibilities in entering, continuing, and leaving the obligation on time and completely"; "each taxpayer is responsible for reporting the start and the finish of obligation, stating the earnings in the months of operation, and keeping the official books and documents which are required according to the tax law".

The TTO employees expressed their opinions about "improvement of the tax consciousness (ethics)" by telling, "taxpayers should accept that the tax is a holy duty, and they should behave with this consciousness"; "taxpayers should know that the services they receive from the community are financed by the taxes collected from them"; "taxpayers should fulfil their duties not as a legal requirement, but as a civic duty or a subconscious rule"; "they should become conscious and put in their subconscious that the tax is collected not by force, but for the development of the country".

Another opinion declared by the TTO employees was "building good relationship with tax office employees". They stated their opinions by saying, "discourse is very important"; "especially the dialog is very important. The dialog of taxpayers with employees should be nice"; "taxpayers should be polite in their relations with tax office employees, and they should leave with satisfaction"; "... moreover, taxpayers should also be more conscious and understanding towards us when they come to the office"; "first of all, taxpayers should adopt mutual respect, love, and tolerance, and we should also respond them in the same way".

The TTO employees made explanations about "having knowledge" by stating, "taxpayers do not know their duties exactly. They only have hearsay information"; "taxpayers, being people with obligations, should have knowledge about their tax payments and relevant sanctions. They usually give these tasks to their accountants, and when there is a sanction they blame the accountants"; "it is very important that taxpayers know the laws"; "taxpayers do not know what works or transactions are performed in what departments"; 
"taxpayers should be knowledgeable about the legal provisions that they will be amenable to during communication with the employee performing the related transaction "; "those who do not have knowledge and not fulfil their duties put both tax offices and themselves into a difficult situation"; "it is necessary to be a knowledgeable and conscious taxpayer. This being the case, taxpayer duties are also fulfilled sufficiently. If there is any problem, it can be solved together".

In regard to "being in contact with the tax office more closely and frequently", while one employee stated, "I think that taxpayers should come to the tax office more frequently. I believe that they shouldn't leave everything to their accountants and they should also follow the transactions themselves", another employee suggested, "Taxpayers, first of all, should not expect the tax-office-related obligations to be fulfilled by their accountants. They should, at least, learn their debts by coming to the tax office. They can learn themselves whether or not the declaration is submitted on time or the debt is paid".

Only one employee expressed an opinion about the finding of "having experienced accountants" and said, "Taxpayers should have experienced accountants who are to fulfil tax-related duties on behalf of them. This way, taxpayers won't encounter a penal sanction at the tax office. We do not have any problems with taxpayers who have sound accountants".

Another employee stated about "Being up-to-date", "one of the duties of taxpayers is to follow the developments and innovations at the tax office and law changes".

Only one employee talked about "following how the taxes are used" and said, "I think it is one of taxpayer's duties to follow in what ways the taxes are returned to them as a service".

An employee told about "considering their accountants as their financial advisors", "busy taxpayers see their accountants not as a financial advisor who helps performing their tax-related transactions accurately and completely, but as someone who helps solving 'how to give less tax' question”.

It is primarily seen that financial and formal obligations were mentioned by all employees as the most fundamental taxing obligation of taxpayers. The employees who listed financial and formal obligations one by one strongly emphasized that taxpayers should be aware of their responsibilities and be careful in taxing procedures. Besides these fundamental responsibilities, some other important obligations were also emphasized (e.g. being up-to-date, following how the taxes are used, building good relations with tax office employees, having knowledge). This indicates that the TTO employees are very certain and knowledgeable about the obligations of taxpayers or what taxpayers expect. On the other hand, a noteworthy point is that responsibility for developing tax consciousness mostly 
belongs to the government, the Ministry of Finance, national education institutions, the Revenue Authority, etc. that are to act in collaboration. However, according to the TTO employees, the development of tax consciousness among taxpayers is under the responsibility of not only above-mentioned associations, but also taxpayers themselves. That means that taxpayers are also charged with this duty, as the TTO employees suggest.

\subsection{The TTO Employees' Opinions Regarding the Fulfilment of the Obligations of Taxpayers Who Are In Contact With the TTO}

The frequency distribution of the answers given by the TTO employees to the question, "Do you think that taxpayers who are in contact with the tax office that you work for fulfil their obligations? Why?" is illustrated in Table 2.

When we examine the data in Table 2, we see that the majority of the TTO employees suggested that "the majority of taxpayers do not fulfil their obligations". While 45 of the employees stated that taxpayers do not fulfil their obligations, 10 employees denoted, "the majority of taxpayers fulfil their obligations" and 8 employees stated, "Some of taxpayers do not fulfil their obligations".

Among the employees who stated that the majority of taxpayers fulfil their obligations, one respondent said that it was due to "having high tax consciousness"; another employee told that the reason was "having consciousness of obligations"; and another suggested that it was because of "being a conscious and concerned taxpayer".

Among the employees who denoted that only some of taxpayers fulfilled their obligations, 3 stated that the reason for the fulfilling behaviour was "having a tax consciousness"; 2 employees suggested that it was due to "being in relation with the public"; 2 others thought it was due to "the application of sanctions"; and 2 other employees said that it was because of "being a corporate taxpayer".

One employee stated his/her opinion regarding the finding of "having tax consciousness" by saying, "80\% of taxpayers fulfil their tax-related obligations. I think the rest don't have adequate tax consciousness". While one employee told in regard to "being in relation with the public", "taxpayers who are in relation with the public fulfil their obligations, but the others do not", another employee suggested, "in general, $30 \%$ of them do fulfil. This segment is mostly the one which delivers and provides services to the public. Moreover, taxpayers who have had audit and inquiry try more to fulfil their duties". 
Table: 2

\section{The TTO Employees' Opinions Regarding the Fulfillment of the Obligations of Taxpayers Who Are In Contact With the TTO}

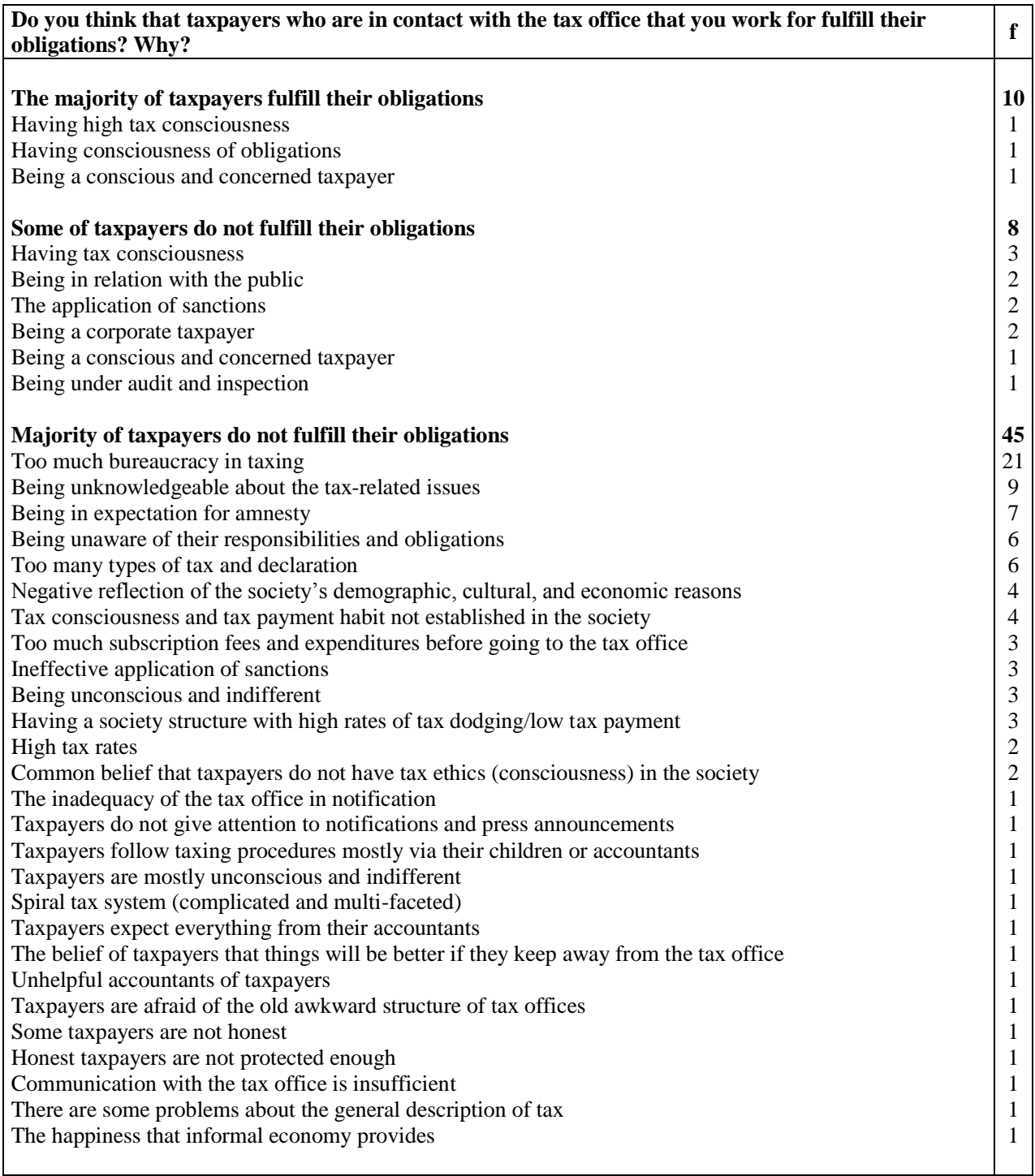

One employee said about "the application of sanctions", "I partly can say yes. While $40 \%$ do fulfil, $60 \%$ do not. First of all, they do not report the start of the business. We 
find out it in the audit. Then they do not receive and print documents. Even though they do, they avoid organizing the documents. When we give a penal sanction, they tell things like 'is it only me?' They do not submit their declarations on time. Even if they do, they do not pay their debts on time. In short, if it wasn't for the sanction, the ones who fulfil their obligations voluntarily would be too rare." In other words, s/he emphasized that the segment who pays the tax debt involves usually those who have had penal sanctions.

Another employee said about "being a corporate taxpayer", "whether or not taxpayers fulfil their obligations varies from person to person (from taxpayer group to taxpayer group), and the ones who do fulfil the obligations are usually the corporate taxpayers".

Among the employees who thought that the majority of taxpayers do not fulfil their behaviours, 21 employees suggested that the reason for this behaviour was "too much bureaucracy in taxing"; 9 of them stated that it was due to "being unknowledgeable about the tax-related issues"; 7 of them said it was due to "being in expectation for amnesty"; 6 of them told that it was because of "being unaware of their responsibilities and obligations"; 6 of them denoted that it was because there are "too many types of tax and declaration"; 4 of them pronounced that it was because of the "negative reflection of the society's demographic, cultural, and economic reasons"; 4 of them remarked that it was because "tax consciousness and tax payment habit are not established in the society"; 3 of them uttered that it was because there was "too much subscription fees and expenditures before going to the tax office"; 3 of them stated that it was due to "ineffective application of sanctions"; 3 of them thought that was because of "being unconscious and indifferent"; 3 of them told that it was because of "having a society structure with high rates of tax dodging/low tax payment"; 2 of them suggested that it was due to "high tax rates"; and 2 of them denoted that it was due to the "common belief that taxpayers do not have tax ethics (consciousness) in the society".

Some of the TTO employees expressed their opinions regarding "being unknowledgeable about the tax-related issues" by saying, "they do not sufficiently fulfil them. That depends on individuals (taxpayer groups). While corporate taxpayers, deliberately, do not fulfil their obligations in order to pay less tax, small scale retailers do not comply with their rights and obligations due to lack of knowledge"; "they do not fulfil. This is because the laws change very frequently and there are too many types of tax. Taxpayers do not know when to pay the tax."; "taxpayers do not have enough knowledge about the financial issues and they behave based on what independent accountants and financial advisors say"; "taxpayers do not know their debts. They do not know what to do with their payment orders"; "they do not do what is required. For example, when they come to make their payments, they learn the amount and what to do. Then they leave and come back. It is a loss of time. And they also request a reduction in the tax amount from the 
employee"; "taxpayers do not know what works or transactions are performed in what departments".

Regarding "being in expectation for amnesty", some of the employees said, "They do not fulfil their obligations. Even the ones who do fulfil them are affected by frequent amnesties"; "they do not fulfil. They do not pay their debts on time and they have thoughts that there will be an amnesty or a new regulation any way"; "they do not fulfil. It is seen that despite all the convenience provided with tax amnesties, they do not pay their debts. The reason should be asked to taxpayers"; "I think not all, but some of them do not fulfil. In tax payments, taxpayers always try to postpone or expect an amnesty all the time".

While one employee stated his/her opinion regarding "being unaware of their responsibilities and obligations" by saying, "I do not think they fulfil. This is because taxpayers do not know exactly what their responsibilities and obligations are towards the tax office", another employee denoted, "taxpayers do not fulfil their responsibilities towards the public. This is due to unconsciousness".

One employee remarked about "there are too many types of tax and declaration", "it is not possible to say that taxpayers who are in relation with our office fulfil their obligations. There are too many types of tax and declaration. They should be reduced".

Some employees out forward their opinions regarding the finding of "negative reflection of the society's demographic, cultural, and economic reasons" by remarking, "since conscious and unconscious people live together in the society, they do not fulfil their obligations due to social, economic, and cultural reasons"; "they do not fulfil. This is because there are taxpayers from various ages, and people may have inadequate educational levels"; "they do not fulfil. It is due to financial problems".

Some TTO employees expressed their opinions regarding "tax consciousness and tax payment habit not established in the society" by stating, "Taxpayers do not fulfil their obligations because they think the societal norms do only exist in formality, and they act with the mentality of tax evasion in essence. Tax evasion policies dominate because the society is not trained on tax as a holy duty through a special course in the national education curriculum or via the Presidency of Religious Affairs"; "they do not fulfil. It is due to moral values. The society doesn't have the consciousness that the tax is a holy duty"; "I think the most important education is about tax in our country. I even think that the importance of tax should be explained very well from the first degree in elementary school. This is because people in this country do not want to pay taxes since they do not know its importance. They consider tax payment as a compulsory work which is a financial power and facility for others"; "when they complain saying that 'the revenue office does nothing other than calculating taxes for me' after we remind them about their tax debts which are not paid, we 
explain them that the tax occurs due to the earnings they declare to the tax office"; "taxpayers should be provided with this mentality, and they should become conscious".

Some of the TTO employees stated their opinions regarding "too much subscription fees and expenditures before going to the tax office" by telling, "until the tax payment is made, taxpayers make many other payments (such as fees of subscription, accountant, notary etc.)"; "the payments that taxpayers make before coming to the tax office should be reduced to the minimum"; "the official payments that taxpayers make other than the tax should be reduced and reflected in the tax"; "they do not fulfil. Taxpayers make ten times more payment outside before coming to the tax office such as notary, chamber, and accountant fees".

Some of the TTO employees stated about "ineffective application of sanctions", "if the penal sanctions of taxpayers who do not pay their tax debts are like those in the western countries, the collection rate will increase"; "I cannot say that taxpayers in relation with our tax office fulfil their obligations. The penalties applied to the ones who do not fulfil their obligations are not adequate"; "taxpayers do not fulfil their obligations not only in our tax office, but in all tax offices in our country. They do not only avoid paying the tax of their earnings, but they also fight with us. It is necessary to have heavy penalties for the collection of the tax revenues. Since the tax amnesty is very frequent in our country, the tax discipline is lost".

One employee said about, "being unconscious and indifferent", "they do not fulfil. When there is a notification sent by our office, they do not care. Especially the time granted (via TV, radio) to them as a deadline is ignored. The announcements and notices made by the press are regarded."

Some employees stated about "having a society structure with high rates of tax dodging/low tax payment" that taxpayers do not fulfil their obligations; avoiding tax payment and tax evasion are considered a sign of a good reputation among the citizens; and tax consciousness is not well-established in the society.

Some employees emphasized regarding "high tax rates" that in Turkey, tax rates are too high, and that has a negative impact on taxpayers' attitudes (i.e. that encourages taxpayers to avoid tax payment and not to fulfil their tax-related duties accurately and completely), and therefore, there are too many informal relationships.

Only one employee put forward his/her opinion regarding "the inadequacy of the tax office in notification" by saying, "taxpayers do not inform the tax office on time, completely, and accurately, and therefore, problems occur in sending notifications (since notifications require too much time and financial costs, the sent notifications are not sufficient), and that has a negative impact on the taxpayers' payment behaviours." 
One employee remarked about "taxpayers do not give attention to notifications and press announcements", "...Again, when a notification is sent by our office, taxpayers do not care enough. Especially the time granted to them as a deadline is ignored. The notifications made by the press (via TV, radio) are not regarded".

Another employee expressed his/her opinion regarding the finding of "taxpayers follow taxing procedures mostly via their children or accountants" by telling, "It cannot be said that all taxpayers fulfil their obligations precisely. I think while $30 \%$ do fulfil, the remaining 70\% fulfil only the half of their obligations. The reason is that they do not follow the taxing procedures themselves, but they follow them via their children or their accountants".

The TTO employees also expressed some other factors having negative impacts on the tax payment behaviours which are as follows:

- Taxpayers are mostly unconscious and indifferent,

- Spiral tax system (complicated and multi-faceted),

- Taxpayers expect everything from their accountants,

- The belief of taxpayers that things will be better if they keep away from the tax office,

- Unhelpful accountants of taxpayers,

- Taxpayers are afraid of the old awkward structure of tax offices,

- Some taxpayers are not honest,

- Honest taxpayers are not protected enough,

- Communication with the tax office is insufficient,

- There are some problems about the general description of tax,

- The happiness that informal economy provides.

According to the research findings, the TTO employees predominantly believe that taxpayers do not fulfil their obligations. The reasons for non-fulfilment can be divided into three based on the employees' opinions: $\underline{(1)}$ the problems related to the Turkish tax system (e.g. too many types of tax and declaration, too many tax amnesties, inability to protect honest taxpayers, high tax rates); $\underline{\text { (2) }}$ the problems related to taxpayers (e.g. the unconsciousness of taxpayers, being unconscious and indifferent, expecting everything from the accountants, insufficient contact with the tax office); $\underline{(3)}$ the problems related to the current societal structure (e.g. tendency for tax dodging/low tax payment, social structure with low tax consciousness, the socio-economic and cultural structure of the society). 
One of the most noteworthy points observed above is that there is no emphasis on the problems related to the tax office. That brings a question to the forefront: Does the related tax office (tax office employees) fulfil its/their obligations completely in their relations with taxpayers? Is there any problem which stems from the tax office and which affects taxpayer behaviours negatively? The potential problems in this context can be revealed through a research on taxpayers.

\subsection{The TTO Employees' Opinions Regarding the Rights of Taxpayers in Their Relations with TTO}

The frequency distribution of the answers given by the TTO employees to the question, "What do you think are the rights of taxpayers in their relations with the tax office?" is illustrated in Table 3.

Table: 3

The TTO Employees' Opinions Regarding the Rights of Taxpayers in Their Relations with TTO

\begin{tabular}{|l|l|}
\hline What do you think are the rights of taxpayers in their relations with the tax office? & f \\
\hline & \\
Total Response & $\mathbf{6 3}$ \\
Increasing the moral satisfaction of taxpayers with tax payment & 34 \\
The right to be informed, assisted, and heard & 22 \\
Receiving friendly, respectful, fair and equal service & 14 \\
Requesting the best service (free from the bureaucracy, fast, transparent, quality, efficient, complete, & 14 \\
understandable, taxpayer-focused) & \\
The right to appeal & 8 \\
The right to have unions of information on taxpayer rights & 7 \\
All kinds of privileges/citizenship rights & 5 \\
Performing taxing transactions through professionals/educated employees & 3 \\
Performing taxing procedures with competent staff at an equipped (with technological systems) office & 3 \\
Finding the staff responsible for the taxing transaction to be performed & 2 \\
Tax confidentiality & 2 \\
Payment of the right taxing amount & 1 \\
Enjoying the agreement, conciliation, and repentance provisions & 1 \\
& \\
\hline
\end{tabular}

As a remarkable point, one of the employees answered the question, "What do you think are the rights of taxpayers in their relations with the tax office?" by saying, "in recent years, the expression of 'taxpayer rights' has emerged. They say it, but they exist only in words. Do employees not have any rights? There should also be something called employee rights. In this building there is no one who is called 'Hakkl' (Hakkl is a male name in Turkish which literally means 'rights of somebody', why?" Another tax office employee suggested, "The taxpayers who make their tax payments to our office on time have a right to request their rights from us. In my opinion, taxpayers who do not fulfil their obligations and 
do not pay their taxes cannot request their rights." The tax office employees focused on various points as is shown in the Table 3.

As it is illustrated in the Table 3, there are various emphases on taxpayer rights. According to the related data, among the TTO employees, 34 employees declared their emphasis on "increasing the moral satisfaction of taxpayers with tax payment", and 22 emphasized "the right to be informed, assisted, and heard". After them, the most emphasized rights were "receiving friendly, respectful, fair and equal service" (14) and "requesting the best service (free from the bureaucracy, fast, transparent, quality, efficient, complete, understandable, taxpayer-focused)" (14). Besides, 8 highlighted "the right to appeal", 7 "the right to have unions of information on taxpayer rights", 5 "All kinds of privileges/citizenship rights, 3 "performing taxing transactions through professionals/educated employees", 3 "performing taxing procedures with competent staff at an equipped (with technological systems) office", 2 finding the staff responsible for the taxing transaction to be performed, and 2 "tax confidentiality". However, the opinions regarding taxpayer rights were mostly expressed without any detailed explanations. That caused difficulty in understanding what exactly they meant with some of the expressions they put forward in listing taxpayer rights. For instance, the finding focused on by the employees most was "increasing the moral satisfaction of taxpayers with tax payment". Since there was no detailed explanation about that, the present study cannot clearly explain what kind of a right they are talking about. This is because; moral satisfaction may refer to various meanings such as feeling that a taxpayer receives his/her reward in response to his/her payments (i.e. the services they pay for and the services they receive are equal), knowing that taxes are collected from everybody equally, seeing and knowing that s/he contributes to the economy by paying taxes. Furthermore, there was not any clear explanation regarding "all kinds of privileges" and "all kinds of citizenship rights" (except for some inadequate explanations such as "taxpayers are always right"). Therefore, it is difficult to understand what kind of right they talked about in their statements. Moreover, the statement that taxpayers have all kinds of privileges and citizenship rights is too broad and implies that it was said without thinking and knowing, which makes it complicated.

On the other hand, although points such as "the right to be informed, assisted, and heard", "the right to appeal", and "tax confidentiality" were not explained in detail by the tax office employees, these were very clear and common fundamental taxpayer rights. One of the employees expressed his/her opinion regarding "receiving friendly, respectful, fair and equal service" by stating, "it is a taxpayer right that s/he is provided with friendly and helpful services during his/her transactions at the tax office. However, as we do it, we also have some rights from them. They should also have nice manners towards us", while another employee stated, "providing all kinds of conveniences and help to taxpayers who fulfil their duties and not causing any difficulties while doing this". 
There were various explanations regarding "requesting the best service (free from the bureaucracy, fast, transparent, quality, efficient, complete, understandable, taxpayer-focused)" such as "the primary right of the taxpayer is to have a fast (computer) system at the tax office"; "taxpayers have the right to request for the best service, while declaring and paying the tax debt. As tax-office employees, we also have the obligation to provide the fastest and the most efficient service within our capabilities"; "providing high quality and on-time service. When they come to the office, they should be treated as a customer who must be satisfied, but not as a taxpayer"; "finding the related person in tax payment. This person should provide a transparent service free from the bureaucracy".

Again, the employees did not provide any detailed explanation regarding "performing taxing transactions through professionals/educated employees", "performing taxing procedures with competent staff at an equipped (with technological systems) office", and "finding the staff responsible for the taxing transaction to be performed".

service.

However, these statements are associated with taxpayers' right to receive the best

Finally, as it was displayed in the Table 3, the findings of "payment of the right taxing amount" and "enjoying the agreement, conciliation, and repentance provisions were stated by only one employee, and there was no further detailed explanation regarding these points. Here, it should be noted that these rights are also among the fundamental taxpayer rights, and they should have been known and emphasized not only by one employee but by all the employees.

When the research findings are examined in general, it can be suggested that the TTO employees have knowledge about the fundamental rights in the category of general taxpayer rights, but this knowledge is not adequate. This is because; some of the points stated as taxpayer rights were uttered without knowledge and were not comprehensive. This inadequacy is also evident from the finding that some of the most fundamental taxpayer rights were stated only by one employee. On the other hand, there are many statements expressed by the TTO employees regarding the special taxpayer rights such as rights during the collection of the taxes, rights during the resolution of the tax disagreements, and rights during the tax audit. For this reason, it can be argued that there is a need to make the TTO employees more knowledgeable and conscious about taxpayer rights. 


\subsection{The TTO Employees' Opinions Regarding the Extent to What TTO Complies With the Taxpayer Rights}

The frequency distribution of the answers provided by the TTO employees to the question "Do you think that the rights of taxpayers are complied with sufficiently at the tax office that you work for? Why?" is illustrated in Table 4.

Table: 4

\section{The TTO Employees' Opinions Regarding the Extent to What TTO Complies With} the Taxpayer Rights

\begin{tabular}{|c|c|}
\hline $\begin{array}{l}\text { Do you think that the rights of taxpayers are complied with sufficiently at the tax office that you } \\
\text { work for? Why? }\end{array}$ & f \\
\hline Observed & 26 \\
\hline Any kind of information and help is provided & 9 \\
\hline The rights of taxpayers are protected in double payments & 2 \\
\hline Taxpayers are welcomed in a nice manner (friendly and polite behaviors) & 2 \\
\hline Taxpayer-focused service is provided (They are always right in our perception) & 2 \\
\hline We are conscious employees complying with taxpayer rights (equipped with sufficient knowledge) & 2 \\
\hline The best service is provided in the existing conditions & 2 \\
\hline Taxpayers seek for their rights & 1 \\
\hline They perform their transactions here more easily than in other institutions and organizations & 1 \\
\hline They can file a claim & 1 \\
\hline They can use a representative (children, accountants) & 1 \\
\hline The employee structure is sufficient in quality and quantity to provide taxpayers' services & 1 \\
\hline There is no problem with taxpayers & 1 \\
\hline There is no privilege given to any taxpayer & 1 \\
\hline The works at the tax-office are conducted orderly and with no fail & 1 \\
\hline We have an equipped office (performing the transactions on the computer) & 1 \\
\hline Taxpayers leave the tax office satisfied and express their satisfaction to the office & 1 \\
\hline Partially observed & 3 \\
\hline There is uniform practice to comply with taxpayer rights (i.e. it depends on the employee) & 1 \\
\hline If the taxpayer isn't aware, his/her rights are not observed & 1 \\
\hline Not observed & 3 \\
\hline Honest taxpayers are not protected enough & 1 \\
\hline $\begin{array}{l}\text { It is believed that employees try to direct and inform taxpayers just because they get benefit from the } \\
\text { situation }\end{array}$ & 1 \\
\hline The unconscious and reluctant working of employees (as if they tried to get rid of taxpayers) & 1 \\
\hline
\end{tabular}

As illustrated in Table 4, the majority of the TTO employees stated, "The rights of taxpayers are sufficiently observed at the tax office that we work for". While 26 of the employees declared that taxpayer rights are observed, 3 of the employees stated that "taxpayer rights are partially observed", and 3 others suggested that "taxpayer rights are not observed". 
Among the employees who stated that taxpayer rights are sufficiently observed, the majority (26) of the employees said, "any kind of information and help is provided"; 9 stated, "the rights of taxpayers are protected in double payments "; 2 told, "taxpayers are welcomed in a nice manner"; 2 denoted, "taxpayer-focused service is provided"; 2 remarked, "we are conscious employees complying with taxpayer"; and 2 uttered, "the best service is provided in the existing conditions".

Regarding the mostly emphasized statement, "any kind of information and help is provided", the employees made explanations such as "I think so. Even though there are some exceptions, employees are trying to provide all the conveniences that they can. They do not cause any difficulties"; "yes, I think so. I see that all my colleagues are helpful to taxpayers. I see that the tax office is helping to taxpayers in all kinds of laws such as tax and amnesty laws by setting an information desk"; "yes. This is because; the exceptions don't break the rule. For instance, nobody here has 'go now and come back tomorrow' kind of attitude, and they try to help taxpayers as much as they can"; "yes, this is because all the help and convenience are provided to taxpayers".

The point receiving the second biggest emphasis was, "the rights of taxpayers are protected in double payments". Regarding this issue, one employee stated, "yes. For instance, even though they have made double payment, they are not aware that they have money in our deposit account. We inform them, deduct it from their debt if they have any, or return it if they do not have any."

There were no further detailed explanations made by the TTO employees regarding the reasons/evidences of the statement that taxpayer rights are sufficiently observed. Some of the employees stated, "Taxpayer rights are sufficiently observed at our office. This is because; taxpayers seek for their rights"; "yes, I think so. This is because the employee structure is sufficient in quality and quantity to provide taxpayers' services"; "yes, this is because taxpayers leave the tax office satisfied and express their satisfaction to the office"; "yes, I think so. This is because; they are always right in our perception"; "Yes, we work perfectly like a clock"; "yes, I think so. The tax office has a taxpayer-focused service"; "yes. Now they can do the transactions on the computer"; "they can learn whatever they want to learn if they apply within the framework of public requirements. They can also learn from the internet"; "they perform their transactions at tax offices much more easily than in other institutions and organizations"; "each citizen (taxpayer) entering the office has all kinds of privileges. It is always their wishes that are fulfilled"; "I think we are providing a very good service in the existing conditions"; "I think the best service is provided within the existing conditions"; "Yes, the employees are equipped with enough knowledge"; "this tax office observes taxpayer rights adequately. This is because; the transactions and procedures are followed by the representatives or accountants of taxpayers"; "yes, I think so. There are no privileges given to any specific taxpayer. Everybody is equal"; "taxpayer rights are observed. On the other hand, taxpayers become more disrespectful towards employees by 
time. They do not pay their debts, and they display disrespectful attitudes. Taxpayers want to use more than what their rights are"; "this tax office complies with taxpayer rights as much as possible. This is because; the transactions and procedures can be followed by the representatives or accountants of taxpayers".

The TTO employees who thought that taxpayer rights are partially observed highlighted, "there is no uniform practice to comply with taxpayer rights. Compliance with taxpayer rights varies from employee to employee"; "I don't think they observe such rights because a request is expected from taxpayers all the time".

The TTO employees who thought that taxpayer rights are not sufficiently observed told, "They are not observed. Employees are trying to get rid of taxpayers. Their concern is to send taxpayers to other employees"; "I think they are not observed because it is believed that employees try to direct and inform taxpayers just because they get benefit from the situation".

When the findings are considered as a whole, it is observed that the majority of the TTO employees share the idea, "the tax office they work for sufficiently complies with taxpayer rights." They put forward some indicators as a proof such as the possibility of taxpayers to perform transactions on the Internet, possibility to use representatives, and leaving the tax office with satisfaction. However, it is necessary to conduct further research on taxpayers in order to increase the reliability of. As a matter of fact, some employees suggested that taxpayer rights are partially observed or not observed at all. Therefore, there is a need to conduct a further study in this matter in order to support the argument that taxpayer rights are observed enough.

\subsection{The TTO Employees' Opinions Regarding the Importance of Taxpayer Rights and Obligations}

The frequency distribution of the answers given by the TTO employees to the question "Do you think it is important to know and comply with taxpayer rights and obligations? Why?" is illustrated in Table 5.

As it is illustrated in the Table 5, all of the TTO employees answering the questionnaire stated that it was important to know and comply with taxpayer rights and obligations.

One of the employees stated in regard to "it ensures better treatment towards taxpayers", "it is important. A complete service should be provided to taxpayers considering them a customer. We should have nice manners to everybody. We should treat taxpayers in a way that we want to be treated". 
Table: 5

The TTO Employees' Opinions Regarding the Importance of Taxpayer Rights and Obligations

\begin{tabular}{|l|c|}
\hline Do you think it is important to know and comply with taxpayer rights and obligations? Why? & f \\
\hline & $\mathbf{6 3}$ \\
Important & 4 \\
It ensures better treatment towards taxpayers & 3 \\
It ensures providing the services justly and in the best way & 1 \\
It ensures the self-control of the institution's activities & 1 \\
It increases the tax ethics of taxpayers & 1 \\
It increases taxpayers' voluntary compliance with taxes & 1 \\
The consciousness of taxpayers also forces the administration to be conscious and knowledgeable & 1 \\
It enables employees to do their jobs in a better way without failing & 1 \\
Better relations can be established with taxpayer, which brings about tax peace & 1 \\
Transactions are conducted more harmoniously when there is mutual understanding & 1 \\
It is a requirement of civilization / human rights & 1 \\
The reputation of a tax office can be increased only through the knowledge of rights and obligations & 1 \\
An employee makes a promise before s/he starts to work & 1 \\
It enables the transparency of tax-office transactions & 1 \\
It shows that the state (the taxing process) is not governed by “I know" approach & 1 \\
It shows that the state (the taxing process) is governed from the bottom & \\
\hline
\end{tabular}

Another employee stated regarding "it ensures providing the services justly and in the best way", "if there is a taxpayer with moral values (the tax is a holy duty) on one side and an employee working with a passion to serve on the other side, a fair world will occur. This is a desired situation". Another employee remarked, "Yes, it is important. We are intermediaries between the laws and taxpayers, and we are supposed to do the requirements in the best and fair way".

The tax office employees delivered their opinions regarding "the consciousness of taxpayers also forces the administration to be conscious and knowledgeable" as follows; "it is important. This is because; it is very difficult for one-sided authority to do self-control. The administration and management can see and know themselves only through reflection. The consciousness of taxpayers also forces the administration to be conscious and knowledgeable. This is a desired situation"; "it is important. This is because; taxpayers should know their obligations. The obligations such as paying the tax on time and filing a claim in unfair situations are important"; "yes, we know what kinds of rights taxpayers have, and we help and inform them accordingly"; "I think it is perfect if both the service receiver and the service provider know because it is a nice feeling to give a conscious service to conscious taxpayers at our office"; "all in all, a better working and taxing conditions may be ensured through interaction about the tax-related duties"; "yes, it is important. The conscious taxing personnel provide the best service to the conscious taxpayer groups"; "it is important. This is because; if they know, they can better follow the things such as legal time granted, exceptions, and reductions which are in favour of taxpayers"; "it is important. 
If everybody knows their rights and they empathize, then the problems will be solved automatically"; "it is quite important. If taxpayers know, and employees respect them, then a peaceful environment will be formed. In this environment, both the service receiver and the provider get happy."

In regard to "better relations can be established with taxpayer, which brings about tax peace", the employees expressed as the following opinions; "it is important. They can have better communication with taxpayers. It can enable the fulfilment of taxpayer rights and obligations"; "tax office employees and taxpayers complement each other. Therefore, tax office employees and taxpayers need to build a strong tie in their relationships in the process of tax collection or declaration or closing of the budget deficit"; "very important. This is because; action always causes reaction, and reaction always causes action. The behaviours such as mutual respect, trust, and justice may result in positive reactions, but just an opposing situation may emerge, too."; "important. If the tax office does not comply with their rights while collecting their money, it can cause taxpayers to avoid the tax office".

The employees stated in regard to "transactions are conducted more harmoniously when there is mutual understanding", "it is important. Transactions are conducted more harmoniously when there is mutual understanding. Here it should be understood that Turkey is governed from bottom, but not from top. It is observed that the things get better, even better."

The employees said about "it enables employees to do their jobs in a better way without failing", "yes, so that employees provide a more efficient service and do the right transactions".

It is evident from the findings that there is a common belief and consciousness about the importance of knowing and complying with taxpayer rights and obligations among all the employees participating in the study. However, it should be noted that there are no further detailed explanations provided about why taxpayer rights and obligations are important and what are the risks and benefits of mutually complying or not sufficiently complying with taxpayer rights and obligations. That indicates that the employees have not reached the sufficient knowledge and conscious level yet; the importance of these rights and obligations is known only based on hearsay; the awareness of employees should be raised in this matter; and they should be trained on this subject.

\section{Conclusion}

The present study, which analyses the extent to what the tax office employees are aware of taxpayer rights and obligations and to what extent they comply with them through an examination of the employees at Tokat Tax Office, suggests that there is a certain level 
of awareness and consciousness among tax office employees about taxpayer rights and obligations. However, such awareness and consciousness are not sufficient because efforts about taxpayer rights and obligations in Turkey are relatively new, and more studies is needed in order to reach a high level of effectiveness in this matter.

Thus, first, it is required to explain taxpayer rights and obligations in a systematic way in Turkey. This is because; even though the majority of taxpayer rights and obligations are regulated in constitutional norms and laws, they do not show any integrity. Second, especially taxpayer rights should be regulated not only as the rules to be observed by tax offices, but also as the rights that may be brought forward by taxpayers, and there should be protective mechanisms. Finally, mutual consciousness should be developed by training tax authorities and taxpayers about taxpayer rights and obligations.

\section{References}

Arslan, C.B. (2008), "The Evaluation of Taxpayer Obligations in terms of Purpose and Scope", $e$ Financial Guide. October-December, 42.

Bentley, D. (1998), “Classifying Taxpayers' Rights”, Taxpayers' Rights: An International Perspective, (Ed: Bentley, D.). Adelaide: Hyde Park Press.

Bentley, D. (2002), "The Significance of Declarations of Taxpayers' Rights and Global Standards for the Delivery of Tax Services by Revenue Authorities", Law Papers, Bond University Law Faculty Publication.

Brzeziński, B. (2010), “Taxpayers' Rights: Some Theoretical Issues”, <http://www.profinfo.pl/img/401/pdf40146684_5.pdf>, 20.12.2014.

Buyrukoğlu, S. \& İ. Eresa (2012), "The Place and Importance of Taxpayer Rights in Creating Tax Awareness", Tax World, (375), 17-127.

Çetin, G. \& R. Gökbunar (2010), “The Tax Administration Employees Perspective Regarding the Taxpayers Rights", Management and Economics, 17(1), 23-46.

Dönmez, R. (2004), “Taxpayer Rights: The Reasons for Emergence and an Attempt for Conceptualization", Journal of Approach, April, 12(36).

Egeli, H. \& M. Dağ (2012), “Taxpayers”’ Rights with Special Reference to Turkish Tax Law”, Journal of Finance, July-December, (163), 130-146.

Er, S. (2011), “Taxpayers' Rights and Public Sector Practices”, Journal of Court of Accounts, AprilJune, (81), 3-32.

Erol, A. (2011), "Evaluation of Taxpayer Rights and Global Values and the Situation in Turkey", Journal of Tax Affairs, 8(89), 18-28.

Gerçek, A. (2006), “Taxpayers' Rights and Survey of the Situation in Turkey”, Journal of Tax Affairs, (209), 121-149.

Gerçek, A. (2009), "Reconstruction of Revenue Administration and Tax Audit: Past, Today, and Future", Journal of Tax Affairs, November, (254), 3-52.

Gökbel, D. (2000), Taxpayer Rights, Anadolu University Institute of Social Sciences, Unpublished Doctoral Thesis, Eskişehir. 
Kızılot, Ş. \& M. Taş (2011), Tax Law and Turkish Tax System, Ankara: Yaklaşım Publishing. Miles M. \& A. Huberman (1994), Qualitative Data Analysis (2nd Ed.), Thousand Oaks, Sage. OECD (2002), Taxpayers' Rights and Obligations-Practice Note, OECD.

OECD (2003), Taxpayers' Rights and Obligations-Practice Note, OECD.

Öz, E. \& B. Karakurt (2007), "Restructuring of Turkish Administration and Final Position”, Journal of Financial, Political, and Economic Commentaries, 44(510), 80-90.

The Republic of Turkey Ministry of Finance (2002), Search for Effectiveness in Revenue Administration, OECD-EU Best Practices, Ankara: European Union Affairs and Foreign Relations Department. 